\title{
LOW-IMPACT DEVELOPMENT: MINIMISING STORMWATER RUNOFF IN A CASE STUDY OF SECTION 13, SHAH ALAM, MALAYSIA
}

\author{
ALAMAH MISNI \& NOOR AIDA FARAIN AMIR SHAHFUDDIN \\ Faculty of Architecture, Planning and Surveying, Universiti Teknologi MARA, Malaysia
}

\begin{abstract}
Urbanisation alters the natural system, such as land cover from natural vegetation and agriculture to urban structures. Such changes are due to the demands of development which significantly change stormwater flow and constructed drainage systems. Problems relating to the present stormwater program have been identified; one of the major environmental effects, as a result of improper stormwater management, is flash floods. Hence, this study focuses on the benefits of landscape approach via the use of low-impact development strategies combined with soft landscape engineering in solving flash flood issues. Section 13, Shah Alam, Malaysia was chosen as the study area as it has experienced serious flash flood problems for many years. Regardless of several solutions, the situation remains the same due to the current water peak runoff which has drastically increased since 2003 as a result of $34.8 \%$ development. This site was also selected due to its rapid development. For these reasons, its current situation was observed and studied. The management of public spaces have been identified as the key factors in improving the current water peak runoff problems. Therefore, design solutions have been proposed for the study area in which the estimation of water peak runoff can be reduced by $7.9 \%$, which is equal to $81.77 \mathrm{~m} 3 / \mathrm{h}$. It is hoped that this study can be used as a guideline in understanding the process of urban environmental enhancement as well as a tool for solving issues related to flash floods.
\end{abstract}

Keywords: flash flood, landscape, low-impact development, stormwater, urbanisation.

\section{INTRODUCTION}

Malaysia is well known as a developing country for which the development and evolution of urban areas are rapidly increasing. The urbanisation era has brought about progressive changes to Malaysia's land use, from the forest, agriculture and other green habitats, to suburban and urban environments. Every change as a result of development will have a longterm impact on the environment during or post construction. Urban development causes significant changes in patterns of stormwater flow from land areas into lower areas of water catchment [1]. Other significant changes may include water runoff and movement during storm events, quality of water, and the ultimate condition of nearby water catchment areas [2]. These changes have proven dramatic effects on natural water movement. The increase in soil erosion problems is due to the limitation of vegetation cover which exposes the soil to the impact of rain [3]. Development has often removed the natural vegetation which allows the reduction of interception and transpiration.

There are several ways to mitigate these negative environmental impacts which are related to the problems of flash floods. One of the ways is through stormwater management with soft landscape engineering treatment; stormwater management can help alleviate these effects. Stormwater comprises pure rainwater, plus anything the rain carries along with it. It is not treated and filtered through the traps. Basically, stormwater management is the control of the surface runoff. This practice is needed to reduce and limit the negative impacts on the environment while enhancing the hydraulic cycle needs of a development [4]. The changes 
are the demands of the development which significantly change stormwater flow and the introduction of a constructed drainage system. One of the major environmental effects of improper stormwater management is flooding. Thus, the aim of this study is to design a functional and liveable urban structure with appropriate treatment of stormwater runoff by the implementation of a low-impact development (LID) approach. Section 13, Shah Alam was chosen as the study area due to its serious flooding problems. It is a small, developing neighbourhood located in a rapidly growing capital city centre.

\section{LITERATURE REVIEW}

According to the MDID [5], floods can be classified into two categories: flash floods and monsoon floods. Flash floods take only some hours to return to the normal water level, while monsoon floods can last for a month. Flash floods of stormwater are the component of stormwater runoff caused by human activities and land development that change the natural water balance. Stormwater management involves the control of surface runoff by reducing stormwater runoff rates and volumes, and also stormwater pollutant load by implementing a method of control at the source [6]. Stormwater management is necessary to mitigate the possible impacts of impervious surfaces. It also involves the careful application of site design principles, construction techniques, and source controls to reduce the impacts of altered hydrology [7].

LID is a management, strategy, or approach of stormwater management that functions to reduce or filter the impact of water runoff while maintaining the hydrology and water quality of the developed area [8]. LID is a strategy used in the management of stormwater that seeks to reduce the impact of runoff and stormwater pollution. It is an ecologically based stormwater management approach favouring soft engineering to manage rainfall on site through a vegetated treatment network. The conveyance practices such as rainwater harvesting, green roofs, soak ways, bio-retention, vegetated filter strips, permeable pavements, perforated pipe systems, and swales also include distributed, small-scale areas. According to the Low Impact Development Stormwater Management Planning and Design Guide [9], the five basic principles of LID design approach involve the use of existing natural systems as the integrating framework for planning, focus on runoff prevention, treat stormwater as close to the sources as possible, create multifunctional landscape as well as educate and maintain the natural system and sources. According to REDAC [6], the sequential flow of the bio-ecological drainage system concept using LID strategies entails the following seven steps:

i. $\quad$ Perimeter swale is used to cater any overload water from any building.

ii. The water will be channelled into an ecological swale.

iii. The excess water runoff is stored in subsurface detention storage.

iv. The excess stormwater is also stored in the dry pond.

v. Water flow from the ecological swale goes into the detention pond and wetland for further water treatment.

vi. The tidal gate will be incorporated at the outlet into the river.

vii. In the case of a flash flood event, the excess water from the detention pond will be directed into the river via the emergency spillway.

Effective LID design requires a deeper understanding of the project site's hydrology, site design, sustainable urban drainage system, water-sensitive urban design, or stormwater source control. 


\section{METHOD}

\subsection{Site study}

The study area was the themed sports area in Section 13, Shah Alam, within the Petaling district of Selangor, Malaysia. The total land/study area is approximately 152.45 ha. The Kuala Lumpur city centre is less than 30 minutes from this study area. This freehold area consists of mixed development areas, dominated by sports facilities centres, commercial, and residential properties. The numerous sports amenities include the Stadium Shah Alam, Stadium Melawati Shah Alam, Go-Kart Circuit, and Shah Alam Extreme Park. This study area is located in strategic locations and linked via the various highways. This area was chosen due to its serious flash flooding problems.

\subsection{Data collection}

Primary data were obtained from a survey conducted by the researcher. The data were collected through qualitative methods by using direct and indirect observations. The research methods were divided into three parts: selecting the study area, finalising the boundary, and conducting the observation of primary data. Direct data collections included the physical condition of the site as well as the activities and categories of users in the study area. The observations and measurements were conducted at the study site for two weeks within the month of April 2016. The indirect data collection in the study area was carried out by taking photographs and recording events.

This primary data collection was handled based on three previous landscape planning studies and data-overlay techniques by Steiner [10], [13], the FAO [11], and Ferguson [12]. Three physical attributes were divided into five parts; land use, slope, microclimate, hydrology, vegetation, and traffic circulation. The secondary data for current and previous developments include land use plans, topography maps, climate data and flash flood events which were obtained from the Selangor Drainage and Irrigation Department, Meteorology Department, Surveying and Mapping Department, and the Shah Alam City Council. A design capacity of the drainage system to hold water runoff could be determined by estimating runoff peak flow rate. Hence, before the development, the year 2003 map was selected because there
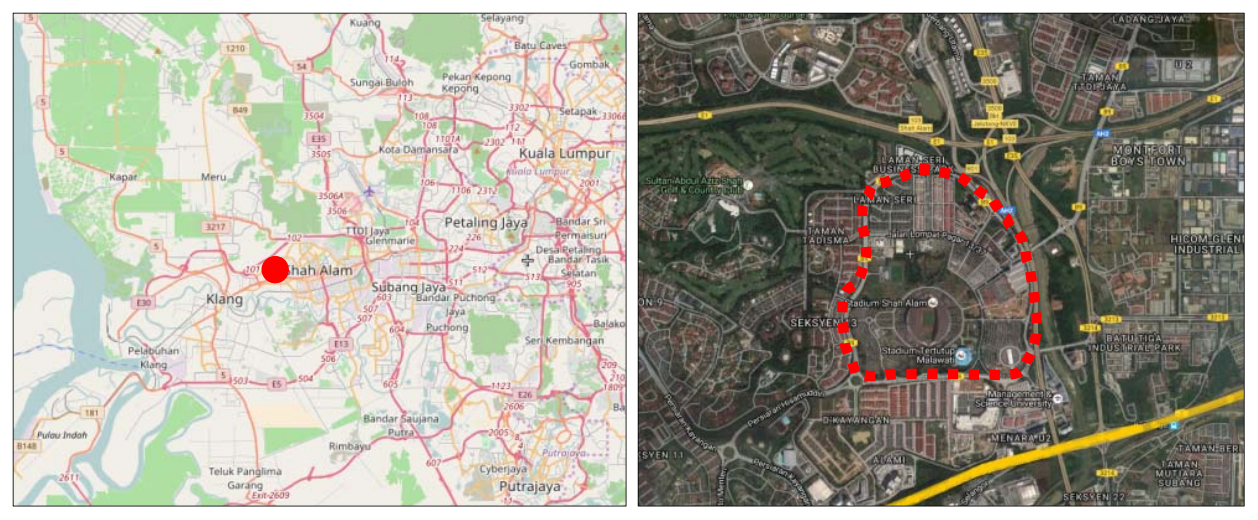

Figure 1: Key and location of study area (longitude $101^{\circ} \mathrm{E}$ and latitude $3^{\circ} \mathrm{N}$ with elevation between 5 and $40 \mathrm{~m}$ ). 
was no recorded flooding history. The two identified watershed zones are watershed A and B. The rational method used to determine peak discharge from drainage basin runoff from the small water catchment area was as follows [14]:

$$
Q=C i A \text {, }
$$

where $Q=$ peak discharge $\left(\mathrm{m}^{2} / \mathrm{h}\right)$

$C=$ rational method runoff coefficient

$i=$ rainfall intensity $(\mathrm{m} / \mathrm{h})$

$A=$ drainage area $\left(\mathrm{m}^{2}\right)$

\subsection{Analysis and synthesis}

All the primary data collected through observation and measurement were analysed and evaluated. The analysis determined the point of issues, concerns, and opportunities of the site study based on the conducted inventory data. To produce a final synthesis map, an overlay technique was used in all the inventory and analysis plans. The overlaid final synthesis map indicated the potential area to be developed to solve the issues and fulfil the aim of mitigating stormwater runoff by the implementation of the LID approach. These kinds of information enhanced the final design approach, including the function of open spaces, parking areas, biological swales, and retention ponds.

\section{RESULTS AND DISCUSSION}

\subsection{Microclimate}

The average annual air and temperature were uniformly high with heavy rainfall and sunshine for about six to eight hours per day.

The dry season occurs between early June and the end of September every year. Monsoon season happens between early November and the end of March. Fig. 2 shows that the month of November was recorded with the highest amount of rainfall. Of the five years (2011-2015), the latest measurement for November 2015 recorded the highest amount of rainfall, reaching more than $800 \mathrm{~mm}$ - the worst case of flooding ever recorded.

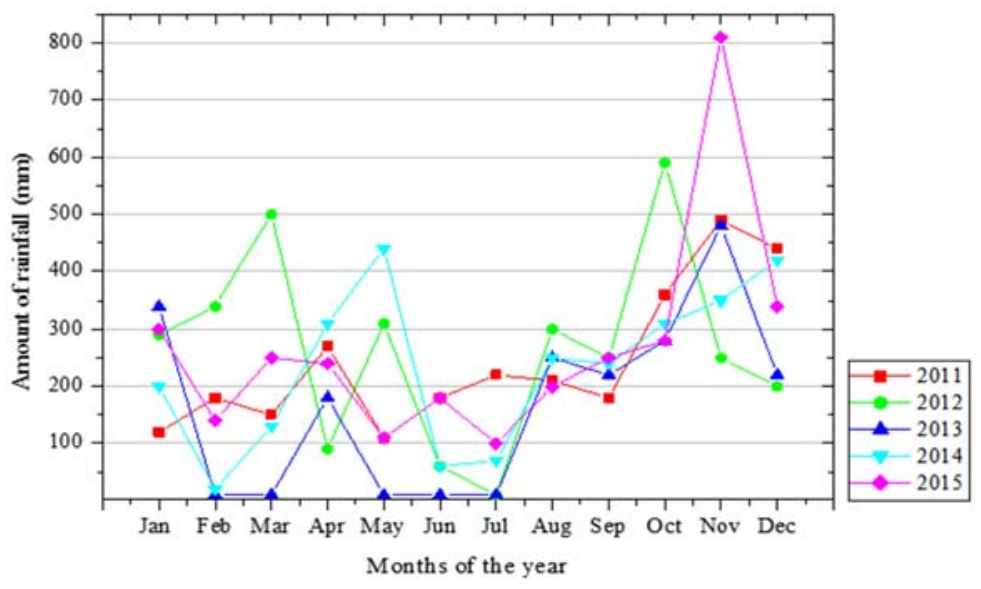

Figure 2: Five years of monthly rainfall measurements in the study area. 


\subsection{Site's flooding history}

Section 13 has experienced the following flooding problems:

a. The first serious flood issue was reported on 26 February 2006. The recorded rainfall amount was $100 \mathrm{~mm}$ and the level of water rise was $0.5 \mathrm{~m}$ in depth.

b. The second flooding occurred on 5 November 2012 where the level of water rise was at $0.3 \mathrm{~m}$ depth and the rain duration was more than three hours.

c. Another serious flooding event reported was on 29 January 2015. The area of flooding was $250,000 \mathrm{~m}^{2}$ and the flood duration was half an hour, where the water level rise was at $0.1-0.3 \mathrm{~m}$ in depth. The rainfall amount was $75 \mathrm{~mm}$.

d. A flooding event was reported again on 12 May 2015. Within two hours, the rainfall was recorded with water levels of at about $0.1-0.3 \mathrm{~m}$ in depth.

e. The latest, most serious and biggest flooding event was on 17 November 2015. The water level rise was at $0.6-0.7 \mathrm{~m}$ in depth and the flood duration was two hours, while the rainfall reading was $100 \mathrm{~mm}$.

The causes of flash flooding were due to the location of the area which is situated in the major, low-lying areas around the Stadium Shah Alam. Furthermore, its surroundings are dominated by impervious surfaces. As the result of the rising impervious surfaces and urban development, the stormwater runoff in the study area has drastically increased. Meanwhile, the current drainage systems cannot afford to hold during a downpour. In addition, the unmaintained drainage system results in rainwater overflows onto roads and low-lying areas.

\subsection{Peak stormwater runoff discharge}

In 2003, the total development in the site study area comprised around half of the total site, while the rest was green. The total peak discharge for the study area was $761.10 \mathrm{~m}^{3} / \mathrm{h}$, where no flash flood occurred. The latest land use (2016) maintained a minimum of $10 \%$ green space. With an increase in developed areas, the surface stormwater runoff was re-calculated, as the 10-year forecast of heavy rainfall occurrence and the intensity of rainfall occurrence is measured per hour. Therefore, the production of runoff in the watershed zones A and B after development was carried out was $1034.12 \mathrm{~m}^{3} / \mathrm{h}$ (Table 1). This result revealed a $34.8 \%$ increase of total peak stormwater runoff discharges, which was due to the decrease in green spaces and the increase of developed areas. Moreover, the area is located on the lower levels. To avoid unforeseen circumstances, the government provides new retention ponds with the perfect volume sizes to hold water during peak water discharge. In this study, the LID approaches and strategies of design were combined with the existing retention ponds.

Table 1: Total peak discharge (2003, and current 2016 development).

\begin{tabular}{|l|l|l|l|l|}
\hline Development & $\begin{array}{l}\text { Watershed } \\
\text { zone A }\end{array}$ & $\begin{array}{l}\text { Watershed } \\
\text { zone B }\end{array}$ & $\begin{array}{l}\text { Total peak discharge } \\
(\mathrm{Q})\left(\mathrm{m}^{3} / \mathrm{h}\right)\end{array}$ & $\begin{array}{l}\text { Difference } \\
(\%)\end{array}$ \\
\hline Before (2003) & 578.8 & 211.2 & 767.10 & - \\
\hline Current (2016) & 747.26 & 286.86 & 1034.12 & 34.8 \\
\hline
\end{tabular}




\subsection{LID approach and strategy}

A composite map was produced by overlaying all inventory maps in Figs 3-5. The lowsensitivity areas are presented in green, medium-sensitivity areas in yellow, and highsensitivity areas in red. The low- and medium-sensitivity areas are intended to be developed using the LID approach, while the high-sensitivity area must be maintained. The design goal of this study is the integration of a stormwater management approach to eradicate the source of the problem (control-at-source) as well as to maintain and restore the natural flow system. The application of an LID technique is meant to provide care for the system, whereas the restoration of the area is to provide continuity between natural bio-ecology and human condition needs. Three design solutions were included in the study: a rain garden, rainwater harvesting, and vegetated swales. Using LID, every infrastructure feature (roof, streets, parking, sidewalks, and green spaces) can be designed to be multi-functional, incorporating detention, retention, filtration, or runoff use.

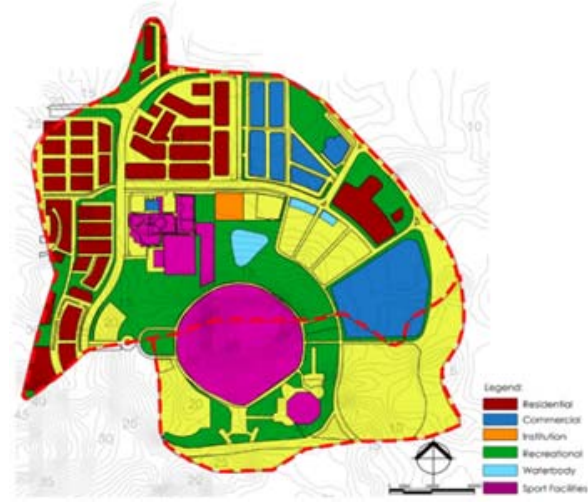

(a)

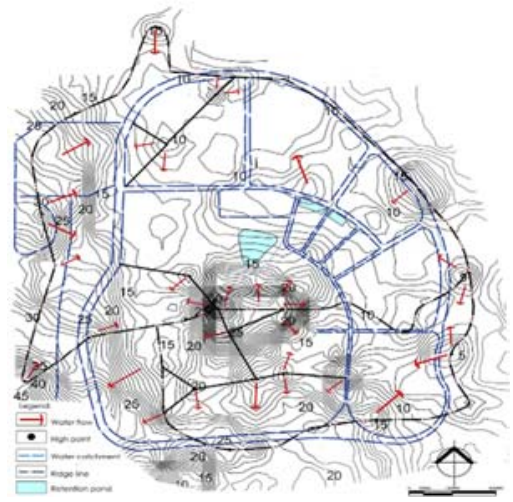

(b)

Figure 3: (a) Land-use map; (b) Hydrology map.

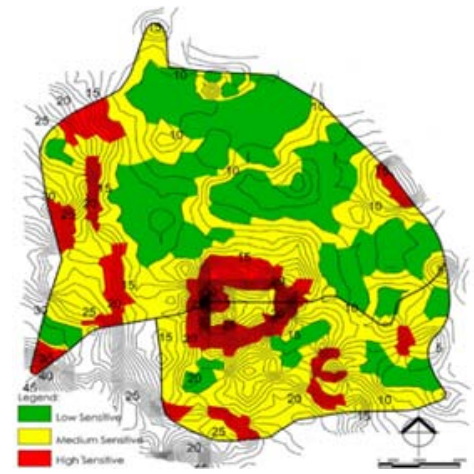

(a)

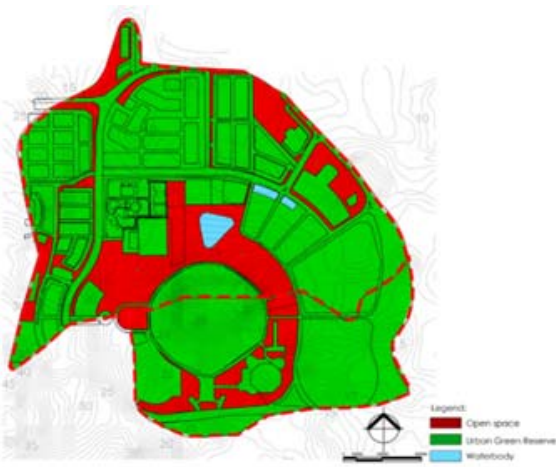

(b)

Figure 4: (a) Slope analysis map; (b) Vegetation map. 


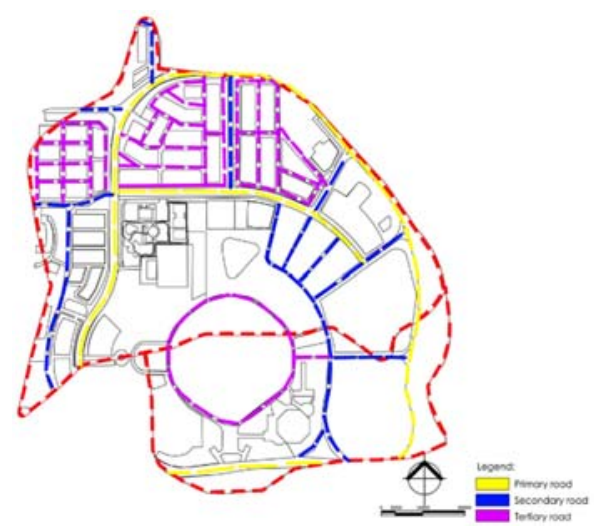

(a)

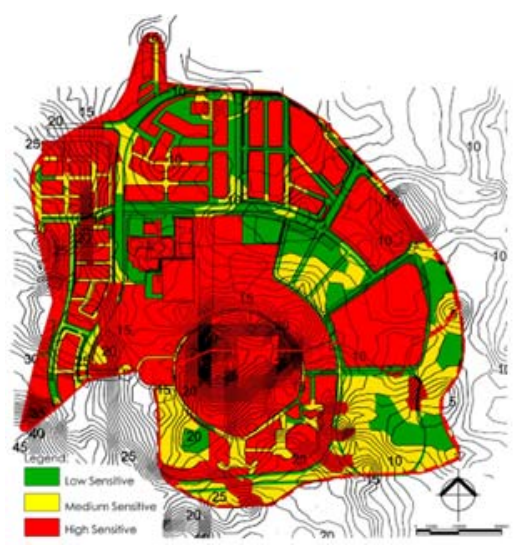

(b)

Figure 5: (a) Traffic map; (b) Composite map.

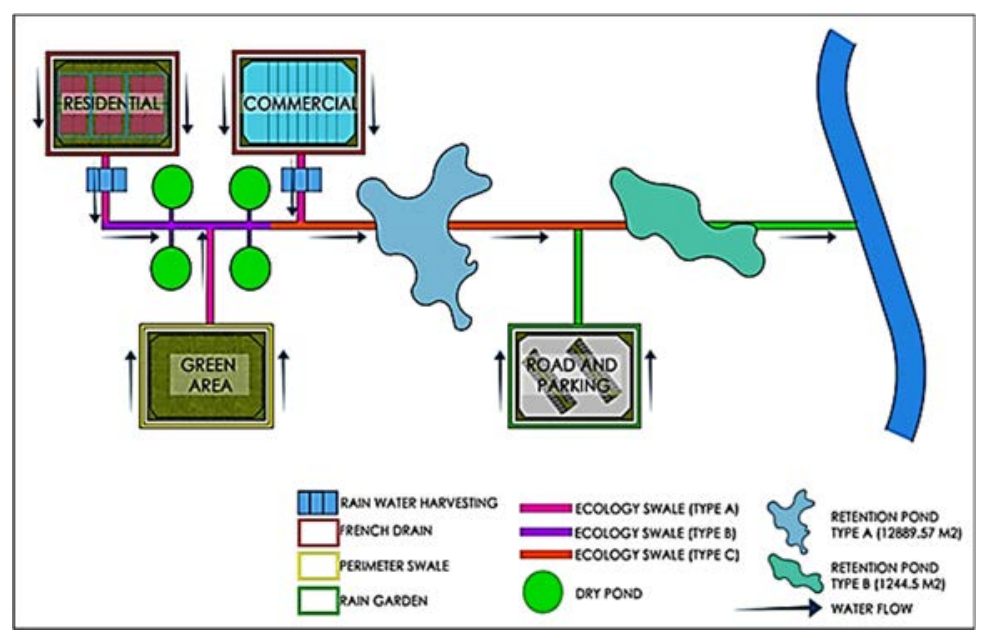

Figure 6: The conceptual schematic layout of the drainage system of a study area.

An overall master plan of the watershed area is a suggested practice of LID. The flow of stormwater is according to the water flow sequence. Hence, a schematic layout of new drainage as shown in Fig. 6 is a mitigation measure based on flooding history. The flood problems cannot be totally solved, but these practices can slow down the water movement while reducing the impact on the environment and the tendency of flooding.

Perimeter swale is used to cater any overload water from any building in the site study. The water runoff from the perimeter swale will be conveyed into the ecological swale which acts as the main conveyor. The excess water runoff is stored in subsurface detention storage. The excess stormwater is also stored in the dry pond constructed with a storage function. The dry pond is a detention basin which has been integrated with the ecological swale to temporarily store the stormwater runoff. This natural detention basin is designed to store up to the surface of $150 \mathrm{~mm}$ excess rainfall and to blend in with the surrounding landscape; it 
should be connected to the ecological swale at the lowest point in order to drain the dry pond system in less than 24 hours. With respect to the need for water quality improvement, the flow from the ecological swale goes into the detention pond and wetland for further water treatment, supported by aquatic plant material. Contaminants are removed either by direct absorption into plant tissues (soluble nutrients) or by physical entrapment and subsequent settlement on the wetland bed. A tidal gate will be incorporated at the outlet of the recreational pond into the Damansara River. In case of a flood event, the excess water from the detention pond will be directed into the river via the emergency spillway.

Porous asphalt pavements are used to provide storm-water management systems that promote infiltration, improve water quality, and at most times eliminate the need for a detention basin. The materials used help in reducing water runoff.

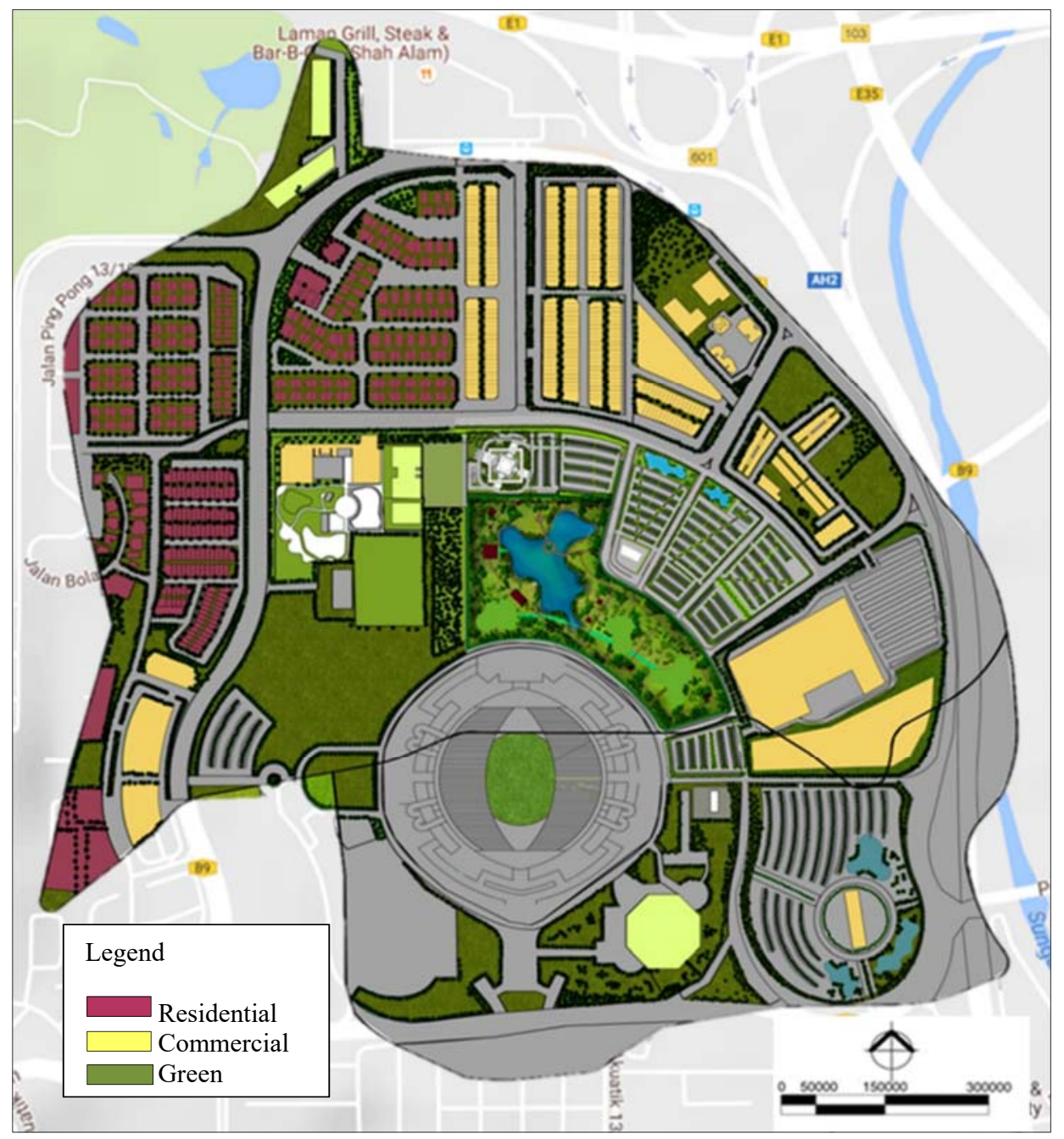

Figure 7: Proposed master plan using LID approaches and strategies for both zones A and B. 


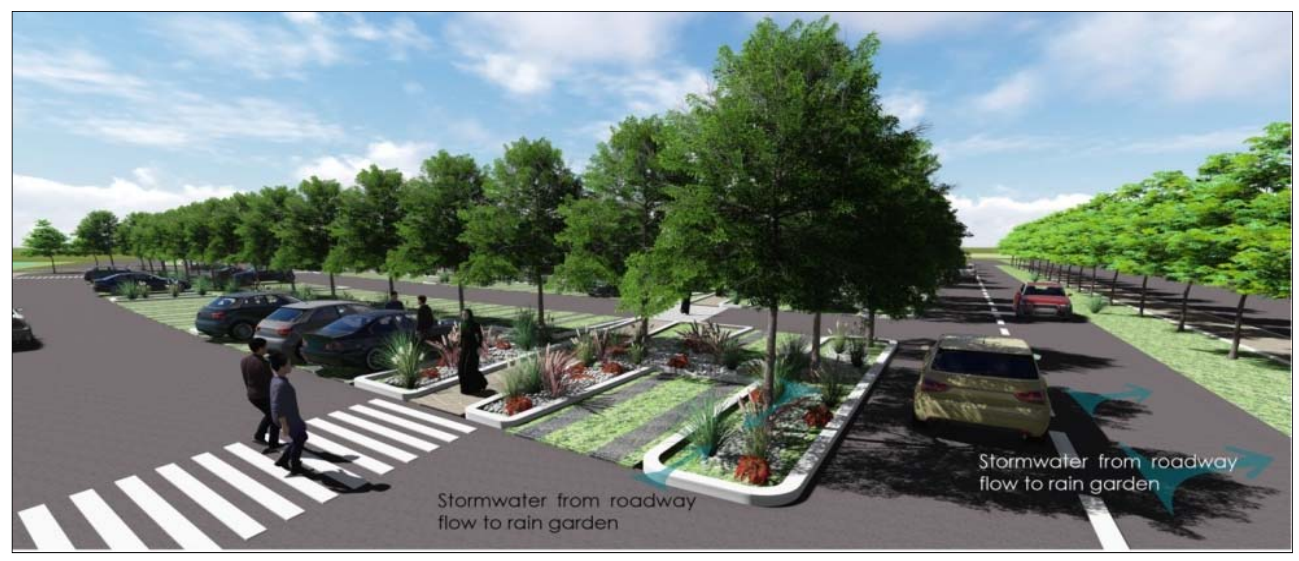

Figure 8: The use of porous asphalt material and a rain garden in the parking areas.

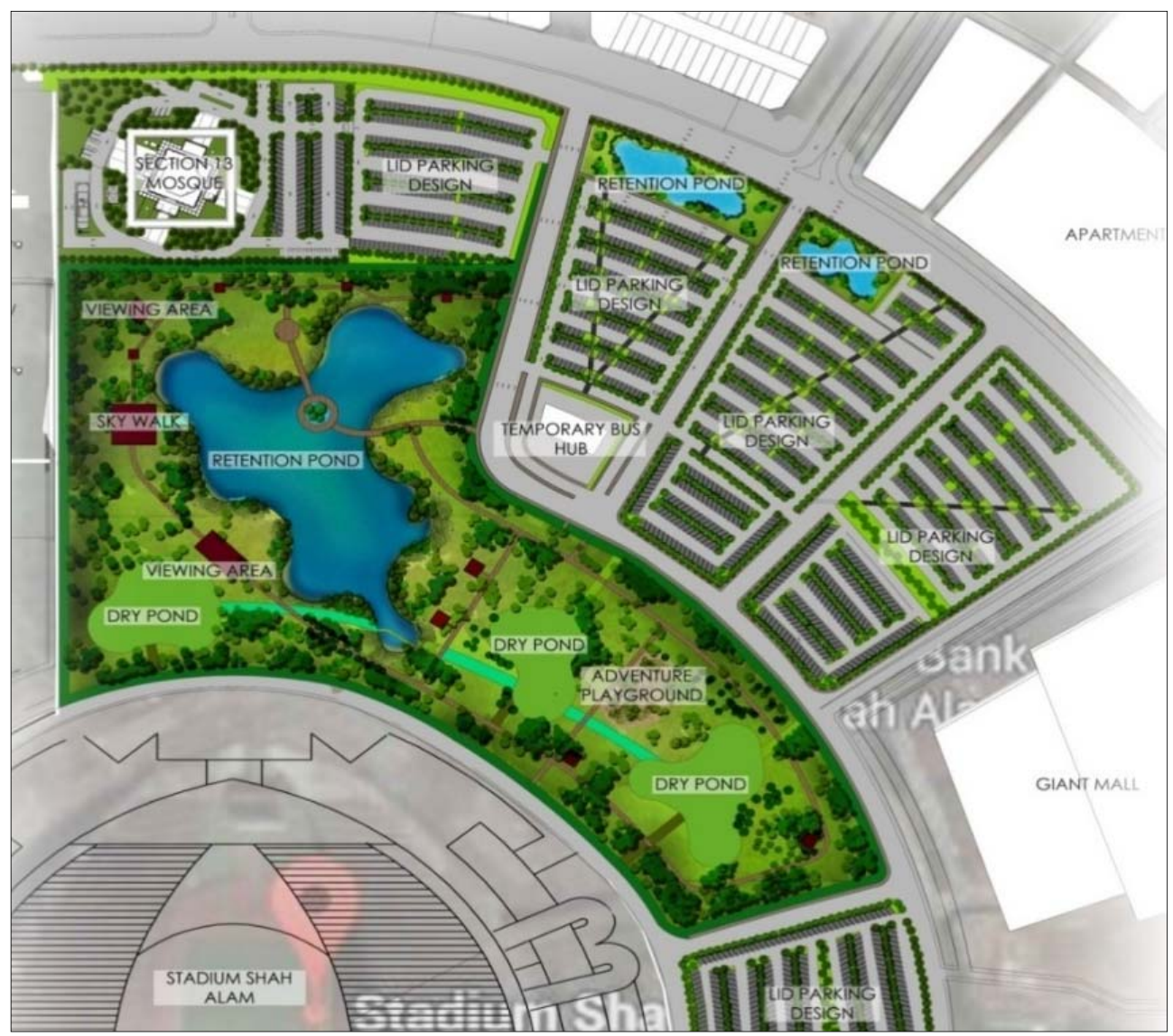

Figure 9: Utilised green/open space areas and parking lots in watershed zone A. 
The main function of the open space in the study area is to support LID approaches and strategies to slow the stormwater runoff. The proposed landscape design is multi-functional. Space will act as a social space for the community as this area is located near to the mosques, stadium, bus hub and sports facilities. The space is made up of public park facilities such as par-courses, gazebos, entrance and continuous walkways.

Planting should be selected from native tropical species. The aquatic plant species must be suitable for the purposes of the rain garden, vegetated swale, and wetland. The function for each plant contributes to the site as they can hold a large amount of water since the area experiences a huge amount of water runoff. Other than that, these plants can help filter the contaminants of the water runoff to produce a better quality of water. Some vegetation such as Salix babylonica and Bambusa sp. help in preventing erosion and sometimes re-vegetate other types of disturbed land. Typha angustifolia and Fimbristylis globulosa are examples of aquatic species with double functions: to filter and hold water. All plant species are in the category of low-maintenance cost, and the whole structure and roots of the plants are considered strong enough to survive.

The design solutions proposed the use of LID approaches and strategies in the study area. Besides providing a vegetated drainage system, the amount of vegetated cover is increased. Changing the paved areas to porous surfaces will slow down the stormwater runoff movement. The estimation of water peak runoff can be reduced by as much as $7.9 \%$ $\left(81.77 \mathrm{~m}^{3} / \mathrm{h}\right)$. Besides the government sectors, the private parties should play an important role in mitigating the problems and maintaining the good condition of this area. Contributions from residents are also needed as one-third of this area is occupied by them; they must also always be aware of and be concerned about the flash flooding events. Therefore, residents should contribute in solving the problems.

\section{CONCLUSION}

The development in the study area contributes to the flooding events as the amount of imperviousness surface increases. This occurs due to the demand of land use of this study area. Even though the demand of this area for development is very high and causes flash floods, there are varying methods to mitigate the problems. Steps should be taken by all individuals to solve the flood problems. LID strategies and practices can decrease the estimated water peak runoff as a result of the current development. The design solutions proposed in the study area consist of increasing the amount of vegetation used, changing materials to porous surfaces, and providing a vegetated drainage system to slow down the water runoff movement. The estimation of water peak runoff can be reduced by $7.9 \%$ $\left(81.77 \mathrm{~m}^{3} / \mathrm{h}\right)$. The species of suggested plants also contributes to the site as these plants can hold a large amount of water. In addition, they can help the filtration of contaminants in the water runoff to produce a better water quality. This study is hoped to educate the local community regarding the process of urban environmental/green enhancement, as well as to mitigate the problems related to flash floods in urban areas.

Table 2: Estimation of total peak stormwater discharge after applying LID.

\begin{tabular}{|l|l|l|l|}
\hline Development & $\begin{array}{l}\text { Current development } \\
(2016)\end{array}$ & $\begin{array}{l}\text { LID approach and } \\
\text { strategy }\end{array}$ & $\begin{array}{l}\text { Difference } \\
(\%)\end{array}$ \\
\hline $\begin{array}{l}\text { Peak stormwater } \\
\text { discharge }\end{array}$ & $1034.12 \mathrm{~m}^{3} / \mathrm{h}$ & $952.35 \mathrm{~m}^{3} / \mathrm{h}$ & 7.9 \\
\hline
\end{tabular}




\section{REFERENCES}

[1] Tucci, C.E.M., Urban Drainage in Specific Climates: Urban Drainage in Humid Tropics, Vol. 1, ed. I.H. Programme, UNESCO: Paris, 2001.

[2] Goonetilleke, A. \& Thomas, E., Water quality impacts of urbanisation, Energy \& Resource Management Research Program, Centre for Built Environment and Engineering Research, Queensland University of Technology, Australia, 2003.

[3] Wang-Erlandsson, L. et al., Contrasting roles of interception and transpiration in the hydrological cycle - Part 1: Temporal characteristics over land. Earth System Dynamics, 5, pp. 441-469, 2014.

[4] Debo, T. \& Reese, A., Stormwater management programs. Municipal Stormwater Management, CRC Press: Boca Raton, FL, 2003.

[5] Malaysian Department of Irrigation and Drainage (MDID), 2016, http://www.water.gov.my/

[6] REDAC, Bio-Ecological Drainage System (BIOECODS): Concepts, Design And Construction, USM: Penang, 2007.

[7] Schueler, T.R., The Importance of Imperviousness, in the Practice of Watershed Protection, Center for Watershed Protection: Ellicott City, MD, 2000.

[8] UACDC, Low Impact Development a Design Manual for Urban Areas, University of Arkansas Community Design Center, 2010.

[9] Dhalla, S. \& Zimmer, C., Low Impact Development Stormwater Management Planning and Design Guide, Toronto and Design, Conservation for the Living City, 2010.

[10] Steiner, F.R., The Living Landscape: An Ecological Approach to Landscape Planning, 2nd ed., Island Press: USA, 2008.

[11] FAO, Land evaluation for forestry - Food and Agriculture Organization of the United Nations, Rome, 1984.

[12] Ferguson, B.K., The use of overlays in site quality mapping. Canadian Journal of Forest Research, 11, pp. 361-369, 1981.

[13] Steiner, F.R., Resource suitability: methods for analysis. Environmental Management, 7, pp. 401-420, 1983.

[14] Thompson, D.B., The rational method, Engineering Hydrology, Civil Engineering Department, Texas Tech University, pp. 1-7, 2006. 